3. Постановление Главного государственного санитарного врача РФ от 09.12.2010 № 163 «Об утверждении СанПиН 2.1.7.2790-10 «Санитарно-эпидемиологические требования к обращению с медицинскими отходами» (вместе с «СанПиН 2.1.7.2790-10). - URL: http://www.consultant.ru/document/cons_doc_LAW_110948/ (дата обращения 03.02.2021).

4. Постановление Главного государственного санитарного врача РФ от 17 февраля 2016 г. № 19 «Об утверждении санитарно-эпидемиологических правил СП 3.3.2.3332-16 «Условия транспортирования и хранения иммунобиологических лекарственных препаратов». - URL: http://www.consultant.ru/document/cons_doc_LAW_ 197563/ (дата обращения 03.02.2021).

5. Постановление Главного санитарного врача Российской Федерации от 24 декабря 2020 г. № 44 «Об утверждении санитарных правил СП 2.1.3678-20 «Санитарно-эпидемиологические требования к эксплуатации помещений, зданий, сооружений, оборудования и транспорта, а также условиям деятельности хозяйствующих субъектов, осуществляющих продажу товаров, выполнение работ или оказание услуг» . - URL: http://www.consultant.ru/document/cons_doc_LAW_373317/(дата обращения 03.02.2021).

6. Постановление Правительства РФ от 03.09.2010 № 674 (ред. от 16.01.2016) «Об утверждении Правил уничтожения недоброкачественных лекарственных средств, фальсифицированных лекарственных средств и контрафактных лекарственных средств». - URL: http://www.consultant.ru/document/cons_doc_LAW_104402/ (дата обращения 03.02.2021).

7. Федеральный закон от 24.06.1998 № 89-Ф3 (ред. от 07.04.2020) «Об отходах производства и потребления» (с изм. и доп., вступ. в силу с 14.06.2020). - URL: http://www.consultant.ru/document/cons_doc_LAW_19109/ (дата обращения 03.02.2021).

УДК 66.088

\title{
Еранская Татьяна Юрьевна
}

Институт геологии и природопользования ДВО РАН,

г. Благовещенск, Россия

E-mail: taerta@mail.ru

Eranskaya Tatiana Yurievna

Institute of Geology and Management, FEB RAS,

Blagoveshchensk, Russia

E-mail: taerta@mail.ru

\section{СПОСОБ УСКОРЕНИЯ ПРОЦЕССА РАЗДЕЛЕНИЯ ПРОДУКТОВ ПЕРЕРАБОТКИ ФИЛЬТРАЦИЕЙ В ЛАБОРАТОРНЫХ ИССЛЕДОВАНИЯХ}

\section{METHOD FOR ACCELERATING THE SEPARATION OF PROCESSED PRODUCTS BY FILTRATION IN LABORATORY STUDIES}

Аннотация. Применение перистальтического насоса при фильтрации плотных азотнокислых растворов ускоряет данный процесс в лабораторных исследованиях в 5-12 раз по сравнению с проточным способом.

Abstract. The use of a peristaltic pump in the filtration of dense nitric acid solutions accelerates this process in laboratory studies by 5-12 times compared to the flow method.

Ключевые слова: фильтрование, плотный раствор, разрежение, насос перистальтический.

Key words: filtration, dense solution, rarefaction, peristaltic pump.

DOI: $10.22250 /$ jasu.93.22

Решение актуальной задачи разработки нового метода ультразвукового разложения каолинового концентрата при производстве глинозема в современных исследованиях ограничивается значительными затратами времени на промежуточные операции - такие как промывка и фильтрация продуктов переработки на двух этапах данной технологии. 


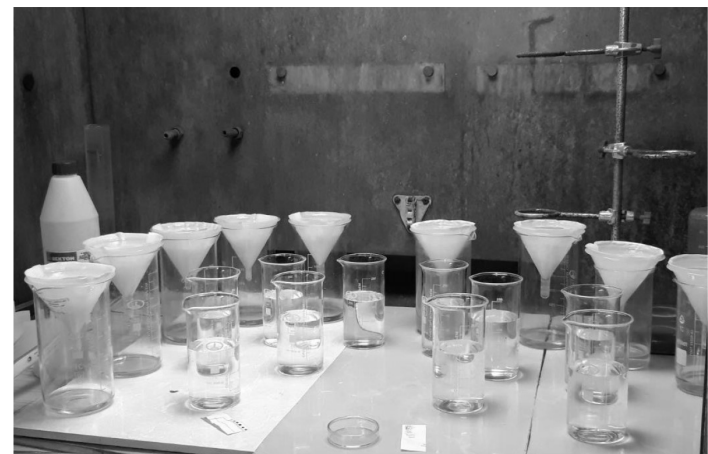

Рис. 1. Фильтрование

без использования насоса.

Получаемые в процессе ультразвукового разложения (выщелачивания) растворы азотнокислого алюминия в избытке азотной кислоты имеют высокую степень концентрации, а следовательно, высокую плотность, что приводит к длительному процессу фильтрации растворов через бумажные фильтры. Фильтрация самих растворов и промывной воды от твердого осадка длится от двух до нескольких рабочих дней. Причем образец распределяется по множеству воронок (рис. 1) с целью создания свободного объема над осадком для промывной воды, что приводит к значительным потерям

компонентов раствора на фильтрах.

Для ускорения данных операций применены перистальтические насосы, обеспечивающие принудительное прохождение жидкости через поры фильтров. Традиционно это оборудование используется в химии, биологии, медицине для дискретной подачи жидкого ингредиента в рабочую зону. В настоящих исследованиях его подключали в обратном направлении - для дискретной откачки воздуха из лабораторного сосуда.

Система фильтрации состоит из самого насоса (рис. 2), силиконовой трубки, колбы Бунзена с пробкой и плотно установленной в ней воронки.

Работа насоса происходит следующим образом. Пара подпружиненных роликов, установленных во вращающейся головке насоса, прокатывается по канавке, в которой расположена эластичная трубка. В зоне перехода канавки к горизонтальному участку ее глубина уменьшается, за счет

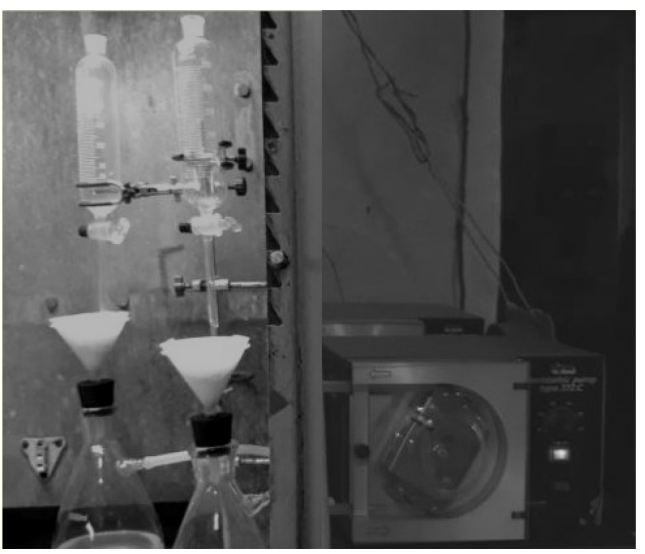

Рис. 2. Комплект оборудования для фильтрования с использованием перистальтического насоса. чего происходит полное или частичное перекрытие отверстия трубки роликом при прохождении данного участка канавки. За роликом в трубке, присоединенной к колбе, образуется разрежение дважды за оборот головки. Таким образом, через некоторое время в колбе создается пониженное давление. Это приводит к принудительному отсосу жидкости через поры бумажного фильтра, а агрессивные газы отводятся через свободный конец трубки в емкость с водой или в вытяжную камеру.

Данный эффект позволяет использовать минимум фильтров, а скорость операции по фильтрованию значительно увеличивается и затрачиваемое время сокращается в 5-12 раз в зависимости от типа и плотности раствора. Конструкция насоса позволяет регулировать степень разрежения в колбе скоростью вращения головки и усилием прижима трубки подпружиненными роликами.

На работоспособность насоса не влияет химически активная среда, так как он устанавливается за пределами вытяжного шкафа, концы трубки (рабочий и свободный) проходят в «грязную» зону через специальные отверстия в стенке шкафа.

Система фильтрации дополнена капельной подачей промывной жидкости. Ее скорость согласована с работой насоса.

Метод позволяет работать с кислыми и щелочными растворами высокой концентрации, так как во взаимодействие с ними вступает только химически стойкая силиконовая трубка. 